\title{
ASUPAN TINGGI NATRIUM DAN LAMA MENONTON TV SEBAGAI FAKTOR RISIKO HIPERTENSI OBESITIK PADA REMAJA AWAL
}

\author{
Vindy Destiany, Muhammad Sulchan ${ }^{*}$ \\ Program Studi Ilmu Gizi Fakultas Kedokteran Universitas Diponegoro \\ Jl.Dr.Sutomo No.14, Semarang, Telp (024) 8453708, Email : gizifk@ undip.ac.id
}

\begin{abstract}
Background : Obesitic hypertension not only occurred in adults but also in adolescents. The prevalence of obesitic hypertension has increased in recent years. Consumption of high sodium foods and watching tv are risk factors were thought to cause obesitic hypertension in adolescents. The study aims to analyze consumption of high sodium foods and watching tv habits as risk factors for obesitic hypertension in early adolescents.

Methods: This study used case control design with a comparator (38 cases and 38 controls). Obesity is determined by weight percentile for age and hypertension percentile determined by age, sex, and height. Sodium intake obtained by semi quantitative FFQ and watching tv habits used watching tv habits questionnaire.

Results: The prevalence of obesitic hypertension is 7,5\%. Consumption of high sodium foods have a significant correlation with incident of obesitic hypertension $(p=0,001 ;$ OR $=7,906)$ while watching tv habits hasn't significantly increases incident of obesitic hypertension but this study show that it has correlation $(p=0,648$; $O R=1,23)$..

Conclusion: The study concludes that consumption of high sodium foods and watching tv habits are risk factors of obesitic hypertension occurrence on early adolescents. The multitude of consumption of high sodium foods and watching to habits factors is respectively 7,9 times and 1,23 times.
\end{abstract}

Keywords: early adolescence; obesitic hypertension; high sodium foods; watching tv habits

\begin{abstract}
ABSTRAK
Latar Belakang: Hipertensi obesitik tidak hanya terjadi pada orang dewasa tetapi juga dapat terjadi pada remaja. Prevalensi hipertensi obesitik pada remaja mengalami peningkatan beberapa tahun terakhir, hal ini dapat berdampak buruk pada saat periode dewasa kelak. Asupan tinggi natrium dan lama menonton tv merupakan faktor risiko yang diduga menyebabkan hipertensi obesitik pada remaja. Penelitian ini bertujuan untuk mengetahui besar risiko faktor asupan tinggi natrium dan lama menonton tv terhadap kejadian hipertensi obesitik pada remaja awal. Metode: Penelitian ini menggunakan rancangan kasus kontrol dengan satu pembanding (38 kasus:38 kontrol). Penentuan obesitas ditentukan berdasarkan persentil berat badan terhadap umur dan untuk hipertensi ditentukan berdasarkan persentil menurut umur, jenis kelamin, dan tinggi badan. Data asupan natrium diperoleh dengan melakukan wawancara menggunakan FFQ semi kuantitatif dan data kebiasaan menonton tv menggunakan kuesioner kebiasaan menonton tv.

Hasil: Prevalensi hipertensi obesitik 7,5\%. Asupan tinggi natrium dan lama menonton tv merupakan faktor risiko kejadian hipertensi obesitik. Asupan tinggi natrium berisiko 7,9 kali ( $p=0,001 ; 0 R=7,906 ; 95 \%$ CI= 2,68-23,25) dan lama menonton tv berisiko 1,23 kali ( $p=0,648 ; O R=1,23 ; 95 \% C I=0,503-3,02)$.

Simpulan: Asupan tinggi natrium berisiko sebesar 7,9 kali dan kebiasaan menonton tv berisiko sebesar 1,23 kali terhadap kejadian hipertensi obesitik pada remaja awal.
\end{abstract}

Kata Kunci: remaja awal; hipertensi obesitik; makanan tinggi natrium; kebiasaan menonton tv

\section{PENDAHULUAN}

Hipertensi obesitik adalah keadaan hipertensi yang dilatarbelakangi kondisi obesitas terlebih dulu, mempunyai karakteristik adanya penambahan volume plasma dan kenaikan curah jantung (cardiac output), hiperinsulinemia dan resistensi insulin, peningkatan aktivitas saraf simpatis, retensi natrium, dan diregulasi salt regulating hormone. ${ }^{1}$ Hipertensi obesitik tidak hanya terjadi pada orang dewasa tetapi juga pada remaja. Pada masa remaja, umumnya mereka akan makan lebih banyak dan sering kali pemilihan makanan dipengaruhi oleh lingkungan sekitar seperti teman, tren yang sedang berkembang maupun keluarga terdekat. Pemilihan makanan harus diperhatikan karena pola makanan yang rendah zat gizi (tinggi gula, lemak, dan natrium tapi rendah vitamin dan mineral) dapat menyebabkan hipertensi obesitik dan akan berdampak buruk pada saat dewasa., ${ }^{2,3}$ 
Prevalensi hipertensi obesitik pada remaja mengalami peningkatan, di Amerika dalam tiga dekade terakhir prevalensi hipertensi obesitik pada anak dan remaja usia 6-17 tahun meningkat dari 7,6-10,8\% menjadi 13-14\%. Prevalensi hipertensi obesitik pada anak usia 6-18 tahun di Rusia sebesar $10 \%$, di Cina sebesar 3,4\%, dan di Inggris sebesar $10-17 \%{ }^{4}$, sedangkan untuk di Indonesia sendiri terutama di kota Semarang prevalensi hipertensi obesitik belum pernah ada. Asupan tinggi natrium dan gaya hidup yang santai (sedentary life style) dalam hal ini lama menonton tv adalah 2 faktor risiko yang sering berpengaruh terhadap kejadian hipertensi obesitik pada remaja.

Data yang didapat dari beberapa penelitian menyatakan bahwa $\leq 1 / 3$ anak usia 2-18 tahun tidak pernah mengkonsumsi buah, $\leq 20 \%$ tidak pernah mengkonsumsi sayuran, dan sebanyak $70 \%$ remaja senang mengkonsumsi kue, biskuit, makanan tinggi natrium dan gula. ${ }^{5}$ Asupan tinggi natrium dapat menyebabkan peningkatan volume plasma, curah jantung, dan tekanan darah. Natrium menyebabkan tubuh menahan air dengan tingkat melebihi ambang batas normal tubuh sehingga dapat meningkatkan volume darah dan tekanan darah tinggi. ${ }^{6}$ Asupan natrium remaja telah melebihi batas yang telah dianjurkan, yaitu 2200 mg perhari. ${ }^{7}$

Gaya hidup masa kini di mana teknologi yang serba canggih dan modern dapat mengakibatkan seorang remaja menghabiskan 5-6 jam sehari untuk tidak melakukan aktivitas fisik yang berarti. Banyaknya program di televisi, permainan dalam komputer, dan video game menyebabkan remaja menjadi malas beraktivitas fisik dan menjadi kurang aktif (sedentary life style). ${ }^{8}$ Lama menonton tv dapat berkontribusi dalam meningkatkan berat badan remaja dikarenakan ketika menonton tv remaja cenderung tidak melakukan aktivitas fisik dalam waktu yang cukup lama. Penelitian di Australia menunjukkan bahwa menonton tv lebih dari 20 jam per minggu atau 2 jam 51 menit per hari berisiko 2 kali lebih besar untuk obesitas remaja. ${ }^{9}$

Penelitian dilakukan di 3 SMP di kota Semarang, yaitu SMP Negeri 3, SMP Ksatrian 2, dan MTS Al Khoiriyah. Penelitian ini bertujuan untuk mengetahui besar risiko faktor asupan tinggi natrium dan lama menonton tv terhadap kejadian hipertensi obesitik pada remaja awal.

\section{METODE PENELITIAN}

Jenis penelitian adalah observasional dengan rancangan kasus kontrol termasuk dalam ruang lingkup gizi masyarakat dan dilakukan pada Mei-Juni 2012. Populasi target dari penelitian ini adalah seluruh remaja awal usia 12-14 tahun di kota Semarang pada tahun 2012 dan populasi terjangkau adalah seluruh remaja awal usia 12-14 tahun di 5 SMP di kota Semarang.

Sebelum penelitian dilakukan skrining awal untuk mengetahui prevalensi hipertensi obesitik pada remaja awal. Skrining awal dilakukan di 5 SMP di Kota Semarang, yaitu SMP Negeri 3, SMP Negeri 30, SMP Kesatrian 2, SMPN 10 Nopember 2, dan Mts Al-Khoiriyah. Selanjutnya dilakukan pengumpulan data yang meliputi identitas sampel, pengukuran tinggi badan, berat badan, lingkar pinggang, pengukuran tekanan darah dan denyut nadi. Pengukuran tinggi badan menggunakan microtoise dengan ketelitian $0,1 \mathrm{~cm}$ dan berat badan menggunakan timbangan injak digital dengan ketelitian $0,1 \mathrm{~kg}$. Pengukuran tekanan darah menggunakan sphygmomanometer dengan ukuran cuff atau manset panjang $17-19 \mathrm{~cm}$ dan lebar 7-9 cm.

Penelitian dilakukan di SMP N 3, SMP Kesatrian 2, dan Mts. Al Khoiriyah. Besar sampel minimal ditentukan dengan menggunakan rumus case control berpasangan, sehingga diperoleh sampel minimal 38 untuk kasus (hipertensi obesitas) dan 38 untuk kontrol (normal). ${ }^{10}$ Sampel kelompok kasus dengan kriteria inklusi yaitu berumur 12-14 tahun, status gizi obesitas ( $\geq 95$ BMI persentil), hipertensi (tekanan darah sistolik dan/atau diastolik $\geq 95$ persentil menurut umur, jenis kelamin, dan tinggi badan) ${ }^{11}$, dan bersedia menjadi sampel dengan mengisi informed consent sedangkan kelompok kontrol berumur 12-14 tahun, status gizi normal (5-94 BMI persentil) dan tidak hipertensi (tekanan darah sistolik dan diastolik $\leq$ 90 persentil menurut umur, jenis kelamin, dan tinggi badan). Data primer yang dikumpulkan yaitu, nama, jenis kelamin, umur, berat badan, tinggi badan, asupan natrium dan kebiasaan menonton Tv. Matching by design dilakukan terhadap variabel umur dan jenis kelamin.

Asupan natrium diperoleh dari wawancara secara langsung menggunakan metode Food Frequency Questionnaire (FFQ). Data asupan natrium dikategorikan berdasarkan WHO sebagai: asupan tinggi natrium bila $\geq 2200 \mathrm{mg}$ untuk kelompok umur 9-13 tahun dan $\geq 2300$ mg untuk kelompok umur 14-18 tahun, sedangkan asupan natrium normal bila $<2200 \mathrm{mg}$ untuk kelompok umur 9-13 tahun dan <2300 mg untuk kelompok umur 14-18 tahun. ${ }^{7}$ Lama menonton tv dihitung berdasarkan lama waktu responden menonton tv 
selama 1 hari dihitung berdasarkan jam diperoleh melalui wawancara dengan pengisian kuesioner tentang kebiasaan nonton tv. Lama waktu responden menonton tv, termasuk menonton video atau bermain, serta semua kegiatan yang dilakukan dengan duduk atau tidur di depan tv. Data lama menonton tv dikategorikan tinggi bila $\geq 2,8$ jam sehari sedangkan normal bila $<2,8$ jam sehari. ${ }^{9}$

Data yang diperoleh di analisis secara statistik, untuk mengetahui besar risiko masingmasing variabel independent terhadap variabel dependent digunakan chi square.

\section{HASIL PENELITIAN}

Hasil skrining awal yang dilakukan pada 1186 responden berasal dari 5 SMP di Semarang dengan melakukan pengukuran berat badan, tinggi badan, lingkar pinggang, denyut nadi, dan tekanan darah, didapatkan 355 responden hipertensi $(30,03 \%), 155$ responden obesitas $(13,11 \%)$, dan 89 responden hipertensi obesitas $(7,52 \%)$. Jumlah responden dalam penelitian ini yaitu 78 orang yang terdiri dari 39 kasus dan 39 kontrol.

Karakteristik responden dalam penelitian ini dapat terlihat pada tabel 1 ;

Tabel 1: Karakteristik responden berdasarkan usia dan jenis kelamin

\begin{tabular}{lcccc}
\hline \multirow{2}{*}{ Variabel } & \multicolumn{2}{c}{ Kasus } & \multicolumn{2}{c}{ Kontrol } \\
\cline { 2 - 5 } & $\mathrm{n}$ & $\%$ & $\mathrm{n}$ & $\%$ \\
\hline Jenis Kelamin & & & & \\
$\quad$ Laki-Laki & 25 & 64,1 & 25 & 64,1 \\
$\quad$ Perempuan & 14 & 35,9 & 14 & 35,9 \\
Total & 39 & 100 & 39 & 100 \\
Usia & & & & \\
12 tahun & 7 & 17,9 & 7 & 17,9 \\
13 tahun & 22 & 56,4 & 22 & 56,4 \\
14 tahun & 10 & 25,6 & 10 & 25,6 \\
Total & 39 & 100 & 39 & 100 \\
\hline
\end{tabular}

Tabel 1 menunjukkan bahwa sebagian sebagian besar responden berumur 13 tahun besar responden adalah laki-laki $(64,1 \%)$ dengan $(56,4 \%)$. kisaran umur sekitar 12 sampai 14 tahun, dimana

Tabel 2. rerata BMI persentil dan tekanan darah pada kelompok kasus dan kontrol

\begin{tabular}{|c|c|c|c|c|c|c|}
\hline & \multicolumn{3}{|c|}{ Kasus $(n=39)$} & \multicolumn{3}{|c|}{ Kontrol $(n=39)$} \\
\hline & rerata $\pm S B$ & Min & Maks & rerata $\pm S B$ & Min & Maks \\
\hline BMI persentil & $98,03 \pm 1,52$ & 93,6 & 99,9 & $40,35 \pm 22,6$ & 6,4 & 83 \\
\hline $\begin{array}{lr}\text { Tekanan } & \text { darah } \\
\text { sistolik } & \text { persentil } \\
(\mathrm{mmHg}) & \end{array}$ & $85,77 \pm 17,34$ & 50 & 99 & $53,07 \pm 10,79$ & 50 & 90 \\
\hline $\begin{array}{lr}\text { Tekanan } & \text { darah } \\
\text { diastolik } & \text { persentil } \\
(\mathrm{mmHg}) & \end{array}$ & $96,2 \pm 2,15$ & 90 & 99 & $64,62 \pm 19,3$ & 50 & 90 \\
\hline
\end{tabular}

Tabel 2 menunjukkan bahwa rerata BMI persentil menurut umur pada kelompok kasus adalah 98,03 $\pm 1,52$ dengan nilai maksimal BMI persentil pada kelompok ini adalah 99,9 dan nilai minimal 93,6. Untuk tekanan darah pada kelompok

kasus baik sistolik persentil dan diastolik persentil lebih tinggi daripada kelompok kontrol. Rerata tekanan darah sistolik persentil kelompok kasus yaitu $85,77 \pm 17,34 \mathrm{mmHg}$ sedangkan rerata tekanan darah diastolik persentil adalah $96,2 \pm 2,15$ $\mathrm{mmHg}$.

Tabel 3. nilai rerata, minimal, dan maksimal asupan tinggi natrium

\begin{tabular}{lcc}
\hline Asupan Na (mg) & Kasus $(\mathrm{n}=39)$ & Kontrol $(\mathrm{n}=39)$ \\
\hline Rerata \pm SB & $2128,5 \pm 834,5$ & $1426,8 \pm 780$ \\
\hline
\end{tabular}




\begin{tabular}{lcc}
\hline Min & 689,1 & 53,5 \\
Maks & 4076,2 & 3439,5 \\
\hline
\end{tabular}

Tabel 3 menunjukkan rerata asupan natrium untuk kelompok kontrol hanya sebesar natrium pada kelompok kasus adalah 1426,8 $\pm 780 \mathrm{mg}$ per hari. $2128,5 \pm 834,5 \mathrm{mg}$ per hari sedangkan rerata asupan

Tabel 4: Tabel silang asupan tinggi natrium dengan kejadian hipertensi obesitik pada remaja awal.

\begin{tabular}{|c|c|c|c|c|c|c|c|}
\hline & \multicolumn{4}{|c|}{ Kejadian hipertensi obesitik } & \multirow[t]{3}{*}{$\bar{P}$} & \multirow[t]{3}{*}{ OR } & \multirow[t]{3}{*}{$95 \% \mathrm{CI}$} \\
\hline & \multicolumn{2}{|c|}{ Kasus } & \multicolumn{2}{|c|}{ Kontrol } & & & \\
\hline & $\mathrm{N}$ & $\%$ & $\mathrm{n}$ & $\%$ & & & \\
\hline Asupan $\mathrm{Na}$ & & & & & 0,001 & 7,906 & $\begin{array}{l}2,68- \\
23,25\end{array}$ \\
\hline Tinggi & 23 & 29,5 & 6 & 7,7 & & & \\
\hline Normal & 16 & 20,5 & 33 & 42,3 & & & \\
\hline Total & 39 & 50 & 39 & 50 & & & \\
\hline
\end{tabular}

Tabel 4 menunjukkan bahwa asupan tinggi natrium pada penelitian ini merupakan faktor risiko kejadian hipertensi obesitik pada remaja awal, dengan besar risiko 7,9 kali ( $\mathrm{p}=0,001$; $\mathrm{OR}=7,906$; $95 \% \mathrm{CI}=2,68-23,25)$. Hal ini menunjukkan bahwa remaja awal dengan asupan natrium $\geq 2200 \mathrm{mg}$ per hari mempunyai risiko 7,9 kali lebih besar untuk mengalami hipertensi obesitik.

Selain asupan tinggi natrium hipertensi obesitik dapat dipengaruhi oleh lama menonton tv, adapun hasilnya dapat dilihat pada tabel berikut

Tabel 5: nilai rerata, minimal, dan maksimal lama menonton tv

\begin{tabular}{lcc}
\hline $\begin{array}{l}\text { Lama menonton tv } \\
\text { (jam) }\end{array}$ & Kasus $(\mathrm{n}=39)$ & Kontrol $(\mathrm{n}=39)$ \\
\hline Rerata \pm SB & $3,2 \pm 1,57$ & $2,9 \pm 1,46$ \\
Min & 1 & 0,5 \\
Maks & 8 & 6,4 \\
Lama menonton tv & & \\
pada saat libur (jam) & $4,2 \pm 1,99$ & $3,76 \pm 1,87$ \\
-Rerata \pm SB & 1 & 1 \\
-Min & 9 & 8 \\
-Maks mama menonton tv & & \\
Lama sekolah & $2,78 \pm 1,58$ & $2,41 \pm 1,3$ \\
pada hari & 0,5 & 0,5 \\
(jam) & 8 & 5 \\
-Rerata \pm SB & & \\
-Min & & \\
-Maks &
\end{tabular}

Tabel 5 menunjukkan bahwa lama menonton tv pada kelompok kasus cenderung lebih tinggi daripada kelompok kontrol. Rerata lama menonton tv pada kelompok kasus sebesar
$3,2 \pm 1,57$ jam setiap harinya sedangkan rerata pada

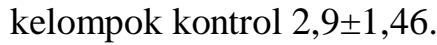

Besar risiko lama menonton tv terhadap kejadian hipertensi obesitik dapat dilihat pada tabel berikut. 
Tabel 6: Tabel silang lama menonton tv dengan kejadian hipertensi obesitik pada remaja awal.

\begin{tabular}{|c|c|c|c|c|c|c|c|}
\hline & \multicolumn{4}{|c|}{ Kejadian hipertensi obesitik } & \multirow[t]{3}{*}{$\mathrm{P}$} & \multirow[t]{3}{*}{ OR } & \multirow[t]{3}{*}{$95 \% \mathrm{CI}$} \\
\hline & \multicolumn{2}{|c|}{ Kasus } & \multicolumn{2}{|c|}{ Kontrol } & & & \\
\hline & $\mathrm{N}$ & $\%$ & $\mathrm{~N}$ & $\%$ & & & \\
\hline Lama menonton tv & & & & & 0,648 & 1,23 & $\begin{array}{c}0,503- \\
3,02\end{array}$ \\
\hline Tinggi & 23 & 29,5 & 21 & 26,9 & & & \\
\hline Normal & 16 & 20,5 & 18 & 23,1 & & & \\
\hline Total & 39 & 50 & 39 & 50 & & & \\
\hline
\end{tabular}

Tabel 6 menunjukkan bahwa lama menonton tv pada penelitian ini merupakan faktor risiko kejadian hipertensi obesitik pada remaja awal dengan besar risiko 1,23 kali ( $\mathrm{p}=0,648$; $\mathrm{OR}=1,23 ; \quad 95 \% \quad \mathrm{CI}=0,503-3,02)$. Hal ini menunjukkan bahwa remaja awal yang mempunyai kebiasaan menonton tv $\geq 2,8$ jam setiap harinya memiliki risiko 1,23 kali lebih besar untuk mengalami hipertensi obesitik.

\section{PEMBAHASAN}

Kejadian hipertensi dan obesitas pada remaja awal mengalami peningkatan dari tahun ke tahun, pada penelitian ini prevalensi hipertensi pada remaja yaitu sebesar $30,03 \%$, prevalensi obesitas sebesar $13,11 \%$, dan prevalensi hipertensi obesitik sebesar 7,52\%. Hal ini dapat diartikan bahwa kejadian hipertensi obesitik telah terjadi pada periode remaja awal. Hipertensi obesitik pada periode remaja dapat berdampak buruk jika tidak segera ditangani karena dapat menyebabkan terjadinya serangan jantung, gagal jantung, stroke, dan gagal ginjal pada saat periode dewasa kelak. ${ }^{12}$

Asupan tinggi natrium pada penelitian ini merupakan faktor risiko kejadian hipertensi obesitik pada remaja awal, dimana asupan tinggi natrium berisiko 7,9 kali untuk kejadian hipertensi obesitik. Hasil penelitian ini sesuai dengan konsensus penelitian yang dipublikasi American Heart Association bahwa asupan natrium yang tinggi pada remaja dapat menyebabkan terjadinya hipertensi obesitik. ${ }^{7}$ Hal ini dikarenakan asupan tinggi natrium dapat menyebabkan peningkatan volume plasma, curah jantung, dan tekanan darah. ${ }^{6}$

Natrium adalah kation utama dalam cairan ekstraselular dan juga merupakan cairan utama yang aktif mempertahankan volume intravaskuler dan intraseluler. Hampir seluruh natrium yang dikonsumsi diabsorbsi, terutama di dalam usus halus. Natrium yang diabsorbsi dibawa oleh aliran darah ke ginjal, disaring, dan dikembalikan ke aliran darah dalam jumlah yang cukup untuk mempertahankan kadar natrium dalam darah.
Secara normal tubuh dapat menjaga keseimbangan antara natrium dan di luar sel dan kalium di dalam sel. ${ }^{6}, 13,14$ Rekomendasi asupan natrium untuk remaja adalah <2200 mg per hari untuk kelompok umur 9-13 tahun dan <2300 mg per hari untuk kelompok umur 14-18 tahun. ${ }^{7}$ Pola makan remaja sangat dipengaruhi oleh lingkungan sekitar, remaja lebih menyukai makanan dengan kandungan natrium dan lemak yang tinggi tetapi rendah vitamin dan mineral. Jenis makanan tinggi natrium yang sering dikonsumsi remaja pada penelitian ini adalah mie instan, sosis, ayam goreng tepung, kecap, dan saos.

Saat remaja terbiasa mengkonsumsi makanan padat energi metabolisme tubuh dapat mengalami gangguan seperti obesitas. Saat obesitas terjadi peningkatan aktivitas saraf simpatis, adanya gangguan pada sensitivitas baroreseptor, peningkatan asam lemak bebas di tubuh dikarenakan aktivitas lipolisis yang tinggi, angiotensin II, insulin, dan leptin. Adanya peningkatan asam lemak akan meningkatkan aktivasi sistem renin angiotensin aldosteron yang dapat menyebabkan peningkatan reabrsorbsi natrium sehingga terjadi retensi cairan dan natrium. Peningkatan $\mathrm{Na}^{+}$dalam darah akan merangsang angiotensin untuk menghambat aktivitas sel dalam melakukan pompa natrium dan meningkatkan retensi natrium. Angiotensin dan $\mathrm{Na}^{+}$akan mengakibatkan peningkatan kalium dalam darah. Kenaikan kalium akan merangsang kelenjar adrenal untuk untuk mensekresi aldosteron. Peningkatan aldosteron ini akan menyebabkan reabsorbsi natrium meningkat sehingga terdapat retensi natrium dan diikuti dengan peningkatan volume plasma, volume cairan ekstraseluler, kenaikan sensitivitas vaskuler, dan akhirnya menekan sekresi renin yang berlebihan. Hal ini akan dikompensasi oleh vasokontriksi dari pembuluh perifer. ${ }^{14,15,16}$

Kondisi seperti ini dalam jangka panjang akan menyebabkan adanya ketidakseimbangan asam basa, kerusakan pada glomerular ginjal dan 
terganggunya fungsi nefron. Reabsorbsi natrium akan semakin meningkat di tubular ginjal dan menyebabkan volume cairan ekstraseluler bertambah sehingga dapat menyebabkan hipertensi. Selain itu peningkatan reabsorbsi natrium dan progresifitas hiperfiltrasi dapat menyebabkan terjadinya gagal ginjal di kemudian hari. $^{14,15,16}$

Lama menonton tv pada penelitian ini merupakan faktor risiko kejadian hipertensi obesitik pada remaja awal, dimana berisiko 1,23 kali untuk kejadian hipertensi obesitik. Hasil penelitian ini sesuai dengan penelitian Francis, Lori, Yoona, dan Leann terhadap remaja perempuan di Australia bahwa lama menonton tv merupakan faktor risiko kejadian obesitas dan dalam jangka waktu lama dapat berisiko menjadi hipertensi obesitik. ${ }^{17}$ Ketika menonton tv remaja cenderung tidak melakukan aktivitas fisik dalam waktu yang lama, di samping itu umumnya mereka akan mengkonsumsi makanan cemilan dalam jumlah yang banyak. Makanan cemilan tersebut biasanya padat energi, tinggi natrium dan lemak, serta rendah vitamin dan mineral. ${ }^{8,}{ }^{18}$ Penelitian ini sebanyak 29 remaja $(37,2 \%)$ terbiasa makan cemilan saat menonton tv dan jenis makanan cemilan yang sering dikonsumsi adalah keripik, kacang kulit, ciki, dan biskuit atau kue kering.

Hasil pada penelitian ditemukan bahwa remaja suka menonton tv saat hari libur atau minggu. Berdasarkan data yang diperoleh remaja pada kelompok hipertensi obesitik terbiasa menonton tv 4,2 $\pm 1,99$ jam sehari sedangkan untuk hari biasa hanya $2,78 \pm 1,58$ jam sehari. Klesges menyatakan bahwa energi basal remaja selama menonton tv cenderung lebih rendah daripada energi basal selama istirahat. ${ }^{18} \mathrm{Hal}$ ini dikarenakan saat seorang remaja tidak atau jarang melakukan aktivitas fisik, tubuh mereka tidak menyadari adanya kelebihan makanan, sinyal dalam tubuh tidak dapat merespon adanya kelebihan asupan makan tersebut sehingga mereka akan cenderung makan terus-menerus. ${ }^{17}$ Energi basal yang rendah mempunyai peran penting dalam hubungan antara kebiasaan menonton tv dengan kejadian obesitas. ${ }^{17,18}$ Keadaan ketika obesitas akan terjadi hiperleptinemia yang dapat menyebabkan peningkatan tekanan darah. Leptin pada remaja obesitas mengalami mutasi sehingga sirkulasi leptin akan meningkat tetapi fungsi leptin untuk menekan nafsu makan dan meningkatkan energi basal terganggu. Dalam jangka waktu yang lama dapat menyebabkan resistensi leptin sehingga tubuh tidak mampu lagi merespon adanya kelebihan asupan makan. 15, 16,17

Data yang diperoleh ditemukkan bahwa remaja terbiasa menonton tv pukul 19.00-21.00 pada hari biasa dan pada hari minggu atau libur mulai dari pukul 07.00-12.00 dan pukul 19.0022.00 dimana acara-acara tv favorit remaja biasa ditayangkan. Data yang ditemukan diketahui bahwa ternyata pemilihan makanan tidak hanya dipengaruhi oleh lingkungan sekitar tapi dapat pula dikarenakan pengaruh iklan cemilan yang biasanya tayang pada saat tayangan acara tv favorit remaja sedang ditayangkan. Iklan makanan cemilan secara tidak langsung dapat mempengaruhi persepsi remaja dalam menentukan makanan yang akan dibelinya, karena iklan lebih sering mengutamakan keunggulan produk. Namun, hal ini tidak disertai informasi lebih lanjut mengenai kandungan gizi yang terdapat dalam makanan cemilan tersebut. Sebagai contoh dalam satu program acara tv favorit remaja biasanya iklan tayang 10 menit sekali dalam 30 menit dan 20-22\% merupakan iklan makanan cemilan. Hal ini meningkat ketika hari minggu atau libur, pada hari libur iklan tayang 10 menit sekali dalam 30 menit dan $40 \%$ merupakan iklan makanan cemilan. Hal ini sesuai dengan penelitian Carter di Australia bahwa iklan makanan cemilan dapat mempengaruhi pemilihan makanan cemilan yang dikonsumsi. ${ }^{9}$

\section{KETERBATASAN PENELITIAN}

Keterbatasan pada penelitian ini yaitu belum dapat dilakukan generalisasi, dikarenakan pada saat pengambilan sampel belum secara random. Sampel yang digunakan hanya siswa dan siswi kelas 7 dan 8 , sementara untuk siswa dan siswi kelas 9 tidak dapat digunakan sebagai sampel karena proses belajar mengajar yang tidak dapat diganggu.

\section{SIMPULAN}

Prevalensi hipertensi obesitik pada remaja awal dari skrining di 5 SMP di kota Semarang sebesar 7,52\% atau 89 anak dari 1186 responden. Asupan tinggi natrium dan lama menonton tv pada penelitian ini merupakan faktor risiko kejadian hipertensi obesitik pada remaja awal tetapi lama menonton tv tidak bermakna secara statistik. Asupan tinggi natrium memiliki besar risiko 7,9 kali dan lama menonton tv memiliki besar risiko 1,23 kali. 


\section{SARAN}

Untuk mencegah terjadinya hipertensi obesitik pada remaja awal sebaiknya mengurangi konsumsi makanan tinggi natrium seperti mie instan, sosis, kecap, dan snack ringan atau ciki dan memperbanyak konsumsi buah, sayur, kacangkacangan, gandum utuh, ikan dan unggas, susu dan produk olahan susu yang rendah lemak serta peningkatan aktivitas fisik dan pengurangan gaya hidup sedentary dapat diterapkan untuk menurunkan tekanan darah dan berat badan. Selain itu pihak sekolah dapat membantu mencegah terjadinya hipertensi obesitas pada remaja dengan membangun kantin sehat di dalam sekolah, sehingga makanan yang dikonsumsi remaja selama di sekolah merupakan makanan yang sehat dan tidak berisiko terhadap kejadian hipertensi obesitik.

Untuk penelitian selanjutnya dapat melakukan penelitian tentang sindroma metabolik pada remaja yang dapat mempengaruhi kejadian hipertensi obesitik pada remaja awal.

\section{DAFTAR PUSTAKA}

1. Sorof J, Daniels S. Obesity Hypertension in Children; A Problem of Epidemic Proportions. Hypertension Journal of the American Heart Association. 2002, 40:441-447.

2. Sarah M. Phillips. Energy-Dense Snack Food Intake in Adolescence: Longitudinal Relationship to Weight and Fatness. Obesity Research Vol. 12 No. 3 March 2004.

3. Story M, Stang J. Nutrition needs of Adolescents. Dalam: Stang J, Story M, editor. Guidelines for Adolescents Nutrition Service. Mineapolis: University of Minesota; 2005.p.21-34.

4. Youfa W, Joana WQ. Standard Definition of Child Overweight and Obesity Worlwide. Brit Med J 2000;321:1158.

5. Bell AC, Kremer PJ, Magarey AM dan Swinburn BA. Contribution of 'noncore' foods and beverages to the energy intake and weight status of Australian children. European Journal of Clinical Nutrition. 2005. 59, 639-645.

6. Charney P. Water, Electrolytes, and Acid Base Balance. In: Krause's Food and Nutrition Therapy. $12^{\text {th }}$ ed. Canada: Saunders Elsevier. 2008. p.150-151.

7. Samuel S. Gidding, Barbara A.D, Leann L.B, Stephen R.D, Matthew W.G, Alice H.L, et al. Dietary Recommendations for Children and Adolescents: A Guide for Practitioners: Consensus Statement from the American Heart Association. Circulation Journal of the American Heart Association. 2005; 112: 2061-2075.
8. Antipatis VJ, Gill TP. Obesity as a Global Problem. In: Bjortorp P. International Textbook of Obesity. John Willey and sons. Uk. 2001. 3-29.

9. Owen B. J. Carter. The weighty issue of Australian television food advertising and childhood obesity. Health Promotion Journal of Australia 2006;17:5-11.

10. Sudigdo Sastroatmojo, Sofyan Ismael. Dasar-Dasar Metodologi Penelitian Klinis. Edisi ke 2. Jakarta: Sagung Seto. 2002.

11. National High Blood Pressure Education Program Working Group on High Blood Pressure in Childrenand Adolescents. The Fourth Report on the Diagnosis, Evaluation, and Treatment of High Blood Pressure in Children and Adolescents. Pediatrics. 2004; 114:555-76.

12. Guyton AC, Hall JE. Buku Ajar Fisiologi Kedokteran: Ed.11. Editor edisi bahasa Indonesia: Lukman Yanuar Rahman,et al. Jakarta: EGC; 2008. hal. 238-241.

13. Sylvia A Price, Wilson LM. Patofisiologi Konsep Klinis Proses-Proses Penyakit. Volume 2 edisi 6. Jakarta: EGC; 2006

14. Horacio JA, Nicolaos EM. Mechanisms of Disease; Sodium and Potassium in the Pathogenesis of Hypertension. The New England Journal of Medicine. 2007; 356: 1977-78.

15. Kotsis V, Stabouli S, Papakatsika S, Rizos Z, dan Parati G. Mechanisms of Obesity-Induced Hypertension. Hypertension Research. 2010; 33: 386-393.

16. Oktavia Lilyasari. Hipertensi dengan Obesitas: Adakah Peran Endotelin-1?. Jurnal Kardiologi Indonesia. 2007; 28: 460-475.

17. Lori A. Francis, Yoonna Lee, and Leann L. Birch. Parental Weight Status and Girls' Television Viewing, Snacking, and Body Mass Indexes. Obesity Research Vol. 11 No. 1 January 2003.

18. David R, Jacobs Jr. Fast Food and Sedentary Lifestyle: a Combination that Leads to Obesity. Am J Clin Nutr 2006:83: 189-90. 